\title{
WHY THE SUPREME COURT SHOULD NOT HAVE DECIDED THE PRESIDENTIAL ELECTION OF 2000
}

\author{
Jesse H. Choper*
}

Bush v. Gore, ${ }^{1}$ the Supreme Court's final decision and last exercise of its immense power of judicial review in the 20th century, will be one of its most discussed rulings for many years to come (although rarely cited-I predict - for its specific substantive holding). ${ }^{2}$ The Justices' assumption of governmental authority reached a new dimension on December 12, 2000, when by a 5-4 margin, the Court affirmed its decision of three days earlier to halt Florida's recount of votes for the presidential election, effectively deciding the contest in favor of Republican candidate George W. Bush. In my view, the Court's intervention in the election was ill advised, not because of the merits of the Court's decision, which has been the dominant subject of both scholarly and journalistic commentary on the ruling, but rather because the proper role of judicial review in our system of government dictates the conclusion that the Court's adjudication was both unnecessary and unwise, creating a widely-based popular perception of partisanship by the Judicial Branch that carries the threat of diminishing the public's trust and confidence in the Justices and endangering the Court's institutional standing and overall effectiveness.

When should the Supreme Court exercise its extraordinary power of judicial review, which is seemingly the most anti-

* Earl Warren Professor of Public Law, School of Law, University of California, Berkeley (Boalt Hall). I wish to thank Pratik A. Shah, Boalt '01, for his excellent assistance in preparation of this comment, and my colleagues, Phillip Frickey, Paul Mishkin, Robert Post, Michael Smith, and John Yoo, my friend Willis Slusser, Boalt '41, and Professor Donald Dripps of the University of Minnesota Law School for helpful comments.

1. 531 U.S. 98 (2000).

2. See infra text accompanying notes $68-92$. 
majoritarian of all exercises of national authority, in direct conflict with our fundamental principles of majoritarian democracy? $?^{3}$ I believe that the Justices should only intervene to secure those constitutional values, mainly found in those constitutional clauses that establish individual rights, that cannot be otherwise adequately protected in the political process. In contrast to disputes concerning federalism (the allocation of power between the national government and the states) ${ }^{4}$ and the separation of powers between Congress and the President, ${ }^{5}$ where the contestants are forcefully represented in the national political process, the interests of those such as racial, ethnic, and religious minorities, political dissidents and persons accused of crime are particularly susceptible to majoritarian indifference or abuse. ${ }^{6}$ By ordinarily limiting judicial review to this category of constitutional provisions, the Court reduces the discord between judicial review and majoritarian democracy and enhances its ability to render enforceable constitutional decisions when its participation is critically needed. ${ }^{7}$ While the Court should not avoid matters based on their controversial nature (and many individual rights cases strongly fit this description), neither should it needlessly dissipate its limited institutional support or "capital."

Although, as will be discussed below, the issues addressed by the Justices in Bush $v$. Gore plainly presented two federal questions, judicial review was not required to secure individual constitutional rights and, more importantly, the central question in the case should have been resolved through the political rather than the judicial process.

At its core, the case confronted the Court with questions of state electoral law - whether the Florida Supreme Court's interpretation of the state's election statutes "impermissibly distorted" the statutory scheme "beyond what a fair reading required" so as to be judicial lawmaking, and thus contrary to Art. I, $\S 2$ of the federal Constitution. ${ }^{8}$ The one notable exception to

3. See Jesse H. Choper, Judicial Review and the National Political Process ch. 1 (U. Chicago Press, 1980).

4. Id. at ch. 4.

5. Id. at ch. 5 .

6. Id. at ch. 2.

7. Id. at ch. 3 .

8. Bush, 531 U.S. at 115 (Rehnquist, C.J., concurring). See infra text accompanying notes $48-53$. 
this non-individual rights type issue-and the basis on which seven members of the Court agreed to reverse the Florida Supreme Court - was the contention that the discretionary procedures being used in the judicially ordered statewide recount of the undervote in Florida, between counties and within certain counties themselves, in order to determine the "clear intent" of the voter, violated the fundamental right to vote on an equal basis secured by the Equal Protection Clause of the Fourteenth Amendment. While judicial review is ordinarily a necessary safeguard against equal protection violations by the political branches of government, ${ }^{9}$ the nature of the equal protection violation alleged in Bush v. Gore did not implicate the typical concern for minority rights. The varying recount standards were neither intended, nor would appear in fact, to be skewed to produce a disparate impact in respect to the votes of any identifiable group, such as a racial minority or a political party. Rather, the choice of standard would seem to promise a random or unpredictable (rather than systematic) effect on whose votes would be deemed valid. ${ }^{10}$ Given this indeterminate result, there is reason to be willing to defer to the local political entities that selected the recount methods, ${ }^{11}$ especially in light of the powerful considerations against the Court's intervention, to be discussed below. ${ }^{12}$

9. See supra notes 6-7 and accompanying text.

10. Professor Dworkin makes a slightly different argument which leads to the same general conclusion: "The Florida court's 'clear intention' standard (taken from Florida statutory law) puts no one at a disadvantage even if it is interpreted differently in different counties. Voters who indent a chad without punching it clean through run a risk that a vote they did not mean to make will be counted if they live in a county that uses a generous interpretation of the 'clear intent' statute; or they run a risk that a vote they meant to make will be discarded if they live in a county that uses a less generous interpretation. But since neither of these risks is worse than the other-both threaten a citizen's power to make his or her vote count - the abstract standard discriminates against no one, and no question of equal protection is raised." Ronald Dworkin, Reply to Fried Letter, XLVIII N.Y. Review of Books 9-10 (Feb. 22, 2001). Professor Chemerinsky reaches a similar conclusion through the argument that Governor Bush had no standing to raise the equal protection claim because "[t]here was no reason to believe that the counting procedure would treat ballots for Bush any differently from ballots for Gore." Erwin Chemerinsky, Bush v. Gore Was Not Justiciable, 76 Notre Dame L. Rev. 1093, 1097 (2001).

11. In contrast, the need for judicial review would be considerably stronger if the claim had been that vote-counting methods were systematically more inaccurate in counties with a higher proportion of members of one of the major political parties rather than the other, or of minority or poor voters. See Dworkin, Reply to Fried Letter at 10 n.3 (cited in note 10 ).

12. Cf. O'Brien v. Brown, 409 U.S. 1, 5 (1972) (per curiam) (staying lower court judgment of equal protection violation because of the availability of alternative forum for resolution "and the large public interest in allowing the political processes to function free from judicial supervision"). 
Further, from an operational standpoint, the process that was in place for determining the unresolved presidential election was working adequately - at least to the extent that litigation is an acceptable method of dispute resolution. Although a whirlwind sequence of legal activity followed the election and automatic recount, ${ }^{13}$ Vice President Gore exercised his challenges pursuant to Florida election law in the Florida courts. ${ }^{14}$ Moreover, nothing prevented those courts from considering Governor Bush's counter arguments based on federal law. ${ }^{15}$ While the presidential candidates battled in the courts, the nation, though anxious-or, at least, impatient - to have a final result, remained stable. Despite some media forecasts and observations by various commentators of a "constitutional crisis," no tangible indications of this seemed to appear. President Clinton still occupied the White House with undiminished authority to conduct the affairs of the nation, even to respond to such tragic emergencies as occurred on December 7 or September 11. Plainly, there was neither the threat nor the reality of any social unrest, violence, or formal military intervention. ${ }^{17}$ The economy remained

13. For a detailed summary of the events leading to the Court's grant of certiorari in Bush v. Gore, see Bush v. Palm Beach County Canvassing Bd., 531 U.S. 70, 73-75 (2000) and Bush v. Gore, 531 U.S. 98, 100-03 (2000) ("[After the automatic recount,] Vice President Gore ... sought manual recounts in Volusia, Palm Beach, Broward, and Miami-Dade Counties, pursuant to Florida's election protest provisions. A dispute arose concerning the deadline for local county canvassing boards to submit their returns to the Secretary of State (Secretary). The Secretary declined to waive the November 14 deadline imposed by statute. The Florida Supreme Court, however, set the deadline at November 26. We granted certiorari and vacated the Florida Supreme Court's decision, finding considerable uncertainty as to the grounds on which it was based. On December 11 , the Florida Supreme Court issued a decision on remand reinstating that date. On November 26, the Florida Elections Canvassing Commission certified the results of the election and declared Governor Bush the winner of Florida's 25 electoral votes. On November 27, Vice President Gore, pursuant to Florida's contest provisions, filed a complaint in Leon County Circuit Court contesting the certification.... The Circuit Court denied relief.... [Gore] appealed.... Accepting jurisdiction, the Florida Supreme Court affirmed in part and reversed in part.") (citations omitted).

14. See Fla. Stat $\S 102.168(2000)$. Governor Bush filed a federal court action. Siegel v. LePore, 120 F. Supp. 2d 1041, 1054 (S.D. Fla. 2000) (brought by George W. Bush, Richard Cheney, and voters of 4 Florida counties) ("A Federal Court has a very limited role and should not interfere except where there is an immediate need to correct a constitutional violation."), aff'd by 234 F.3d 1163, 1163 (11th Cir. 2000) (en banc). See also Touchston v. McDermott, 234 F.3d 1133 (11th Cir. 2000) (brought by voters of Brevard County, Florida and decided along with Siegel v. LePore).

15. In fact, the dissenting opinions in the Florida Supreme Court discussed both the Article II and equal protection concerns. Gore v. Harris, 772 So. 2d 1243, 1268, 1272 (Fla. 2000) (Wells, C.J., Harding, J., dissenting)

16. See infra text accompanying notes $69-80$.

17. See Gore's Time Ran Out: Democracy Wins, Chicago Sun-Times 53 (Dec. 13, 2000) (" $[T]$ here were no soldiers taking over the streets, no general or colonel assuming control of the country."). 
stable. $^{18}$ There was not even any serious name-calling by the competing camps, at least not beyond the usual election season fare. Rather, the contestants proceeded in the American waythey sued! And the American public was afforded an unusual opportunity to observe the path of the rule of law in action. ${ }^{19}$

The real difficulty was not the dispute resolution process. Rather, the problem was the unusual circumstance that there was no practically ascertainable winner of the presidential election of 2000, which essentially ended in a tie. If, as Professor Charles Fried explains, there was no way to design a statistically valid recount because "a difference of 0.5 percent in an election in which a hundred million votes were cast-at various times, under diverse circumstances, by a wide variety of meansexceeds our present capacity for accurate tabulation, ${ }^{20}$ then that

18. During the period following the election until Bush v. Gore was decided, the stock market fell, which some analysts attributed to the uncertainty regarding the election outcome. See, e.g., E.S. Browning, Uncertainty on Election Hurts Stocks, Wall St. J. C1 (Nov. 29, 2000); E. S. Browning, Vote-Count Saga Spurs Stock Fall, Wall St. J. C1 (Nov. 10, 2000). However, it is difficult to trace the harm to the disputed election, and other analysts reject this explanation as a major cause of the downturn. See, e.g., Gregory Zuckerman, Market Woes May Outlast Election, Wall St. J. C1 (Nov. 13, 2000). In fact, the market began falling before the election and continued to fall for some time thereafter. See, e.g., Jonathan Fuerbringer, New Bush Status Does Little to Fuel Sustained Rally, N.Y. Times C10 (Dec. 14, 2000).

19. As Professor Elizabeth Garrett persuasively characterizes the situation:

Unlike other instances in our history where the presidential election ended in a dispute, no armed forces were gathering. Nor was the country at a critical historical juncture, as it was in 1876 , when it faced rebuilding part of the country in the wake of a civil war. Instead, we watched as local and state officials tried to apply a rather confusing statutory structure to unanticipated events. We learned about the relationship of elected administrative officers like the secretary of state to the state courts and to the state legislature. We saw the interaction in a federal system of state and national entities. We listened as appellate justices at the state and national levels asked probing and difficult questions. To the extent that people were paying attention-and a good number of us were-we were also learning about how a stable democracy deals with problems that arise in elections.

Elizabeth Garrett, Leaving the Decision to Congress, in Cass Sunstein and Richard Epstein, eds., The Vote: Bush, Gore and the Supreme Court 50 (U. Chicago Press, 2001).

20. Charles Fried, Letter to the Editor ('A Badly Flawed Election': An Exchange), XLVIII N.Y. Review of Books 8-9 (Feb. 22, 2001). Professor Fried's assessment seems to be confirmed by the conflicting reports of several early independent recounts in Florida. See, e.g., Stephanie Desmon, Florida Recounts Fall Short of Unanimous: Results and Methods Clash During Reviews of Presidential Votes, Baltimore Sun 1A (Mar. 24, 2001); Michael Kranish, Fla. Media Recounts Offer Mixed Results, Boston Globe A1 (Mar. 19, 2001). For a subsequent venture, see Dennis Cauchon and Jim Drinkard, Special Report: Florida Voter Errors Cost Gore the Election, USA Today 1A (May 11, 2001) (reporting the results of a study of 111,261 uncounted overvotes by USA Today, The Miami Herald, and five other Florida newspapers that the hypothetical winner would have depended on which review standard was used, with Bush winning under the strict standards and Gore under the lenient standards); AP, All-Florida Recount: Still No Clear Winner; More Democratic Ballots Had Errors, Seattle Times A1 (May 11, 2001) (same). See also infra 
was multitudinously true in Florida where no count or recount ever reached a difference as large as a thousand votes out of six million cast $(.0167 \%){ }^{21}$ It may well be that the fairest solution (clearly the quickest and least costly) would have been to flip a coin. ${ }^{22}$ Such means, however, strike many citizens as unacceptable because of our national sense of propriety and admirable belief in the search for "truth," both of which might affect the coin-toss winner's mantle of legitimacy to govern.

Finally, from the perspective of both public policy and constitutional doctrine, Bush v. Gore presented a "political" question. ${ }^{23}$ On its face, the ultimate issue in Bush v. Gore-who shall be elected president of the United States - is the most "political" of all matters in our nation. As a matter of policy, our governmental system erects a formidable presumption that political issues should be resolved by political means, so as not to embroil the Court in partisan political maneuverings beyond its institutional capacity and role. ${ }^{24}$

note 33 .

21. See Richard A. Posner, Breaking the Deadlock ch. 2 (Princeton U. Press, 2001).

22. In fact, several state statutes expressly provide for a coin flip to determine election ties. See, e.g., La. Rev. Stat. Ann. 46:1410(C)(3) (West, 2000) ("In case of a tie, the secretary of state shall invite the candidates to his office and shall determine the winner by the flip of a coin."); Mo. Rev. Stat. 162.492 (2000) (1978 Amendment deleted former subsec. 6 , which provided that a tie vote would be determined by the flip of a coin); N.D. Cent. Code $\S \S 16.1-11-38,16.1-14-0,16.1-15-29,40-21-17,58-04-15$ (2000) ("In case of a tie vote the nominee or nominees must be determined by a coin flip ...."). See also Huber v. Reznick, 437 N.E.2d 828, 839 (Ill. App. 1982) (holding that trial court did not err in choosing a coin flip as the method of determining the winner of the tie vote by lot); N. M.Stat. Ann. $\S 1-13-11$ (2000) ("candidate chosen by lot... in the event of a tie vote"); Reuters, Election 2000; The Presidency; High Stakes; If Vote is Tied in New Mexico, Poker Hand Could Settle It, Newsday A05 (Nov. 15, 2000) (describing practice of using "one hand of five-card poker").

23. Here, I use the term "political question" both as a "term of art" and more loosely (as commonly understood), referring to it both as a constitutional constraint as well as a prudential tool to limit the Court's jurisdiction. In the less formal sense, the Court could have avoided deciding the question embodied in Bush v. Gore in several ways short of expressly finding it nonjusticiable under Article III: denial of certiorari in the first case, denial of certiorari in the second case, or denial of the stay.

24. See infra Part III (discussing the perception of partisanship that tainted the Court by reviewing Bush v. Gore); Michael C. Dorf, Supreme Court Pulled a Bait and Switch, L.A. Times B11 (Dec. 14, 2000) (criticizing the Court for overreaching in "deciding issues that are perhaps best left to the political process," and commenting that the "wisest course for the court may have been to stay out of the presidential contest entirely"). Along related lines, Professor Alexander Bickel argued for judicial restraint in resolving political disputes, especially in cases marked by, among other things, the "strangeness of the issue," its "intractability to principled resolution," its "sheer momentousness ... which tends to unbalance judicial judgment," and "the inner vulnerability, the self-doubt of an institution which is electorally irresponsible and has no earth to draw strength from." Alexander M. Bickel, The Least Dangerous Branch 184 (Bobbs-Merrill, 1962); cf. Gerald Gunther, Judicial Hegemony and Legislative Autonomy: The Nixon 
The issue in Bush v. Gore also qualifies as a "political question" under a more formal doctrinal analysis by which, pursuant to separation of powers principles, the Court defers to the political branches for final determination of certain constitutional issues. ${ }^{25}$ The first, and seemingly most important ${ }^{26}$ of the four criteria that the Court considers in determining the existence of a political question - whether there is a "textually demonstrable constitutional commitment of the issue to a coordinate political department" ${ }^{27}$ - strongly suggests that the core issue in Bush v. Gore was nonjusticiable. The Twelfth Amendment (which supplants provisions of Art. II, $\S 1$ dealing with the Electoral College) expressly remits to the House of Representatives (plainly that organ of the national government originally intended to be most responsive to the will of the people) ${ }^{28}$ the authority to choose the President if no candidate receives a majority of the electoral votes. ${ }^{29}$ Furthermore, the Electoral Count Act, a set of federal statutes enacted after the Hayes-Tilden election ${ }^{30}$ to im-

Case and the Impeachment Process, 22 U.C.L.A. L. Rev. 30 (1974) (criticizing the Supreme Court for prematurely cutting off the political process of impeachment in the House of Representatives, a more appropriate forum). See also Stuart Taylor, Jr., Mr. Justice Taylor Presiding, Legal Times $73-75$ (Dec. 4, 2000) (arguing that Bush v. Gore presented a political question because "[i]f, in the end, people on the losing side believe that Congress or the Florida Legislature has flouted the will of the people, their remedy must lie at the polls, not in any courtroom").

25. See Nixon v. United States, 506 U.S. 224 (1993); Baker v. Carr, 369 U.S. 186 (1962).

26. See Nixon, 506 U.S. at $230-31$ (focusing the analysis on the commitment of the impeachment power to the Senate through both the text of Constitution ("sole" power) and the Framers' intent).

27. See cases cited supra note 25 . There is also a strong argument that the judgment that effectively determines who shall be president is "of a kind clearly for nonjudicial discretion," that such judgment implied "lack of respect due coordinate branches of government," and that it carries the "potentiality of embarrassment from multifarious pronouncements by various departments on one question." Baker, 369 U.S. at 217 (Frankfurter, J., dissenting).

28. Constitutional Convention delegate Thomas Johnson expressed the direct representative role conceived for the House of Representatives in contrast to that for the Senate: "[I]n some respects the States are to be considered in their political capacity, and in others as districts of individual citizens, the two ideas embraced on different sides, instead of being opposed to each other, ought to be combined; that in one branch [the House] the people, ought to be represented; in the other [the Senate] the States." Thomas A. Bailey, The American Pageant 140-41 (Heath, 3d ed. 1966); see also Page Smith, The Constitution-A Documentary and Narrative History 175 (William Morrow and Co., 1978). The Framers' decision to provide for popular election of House members in contrast to state legislature elections of Senate members and electoral college election of the President irrebuttably demonstrates the House's more populist origins. See U.S. Const., Art. I, \$§ 2-3; Art. II, \$1.

29. U.S. Const., Amend. XII.

30. In passing the Electoral Count Act in 1887, which expanded previous legislation enacted in 1845 , Congress was acutely aware of the dangers of Supreme Court Justices 
plement Congress's task under the Twelfth Amendment to count the electoral vote, assigns to Congress the authority and responsibility to settle disputes remaining after a state has tried to resolve electoral contests through "judicial" (which Florida expressly chose to do $)^{31}$ or other means. Notably, neither the Constitution nor the federal statutes mention any role for the Supreme Court in this "adjudicative" process. ${ }^{32}$

deciding election outcomes after the Hayes-Tilden presidential election of 1876 . In that election, three states each sent two slates of electors, whose votes would decide the election. Congress appointed an electoral commission composed of five Senators, five Representatives, and five Supreme Court Justices. The Commission divided along partisan lines, and the deciding vote fell to Justice Bradley, who immediately became the object of charges of partiality. See Bush v. Gore, 531 U.S. at 153-57 (Breyer, J., dissenting). For the criticism leveled at the performance of all the Justices, see C. Vann Woodward, $R e$ union and Reaction: The Compromise of 1877 and the End of Reconstruction 165-74 (Little, Brown \& Co., 1956). Professor Bickel concluded that while Bradley acted honestly and followed legal principles, "in the circumstances the issue of principle was trivial, it was overwhelmed by all that hung in the balance, and it should not have been decisive." Bickel, The Least Dangerous Branch at 185 (cited in note 24).

31. See Fla. Stat. $\$ 102.168(2000)$. Because the Electoral Count Act anticipates involvement of a state's courts in resolving controversies regarding the appointment of that state's electors, and because any decision of the Florida Supreme Court would ultimately be "appealed" to Congress, see infra notes 35-36, the Florida courts' involvement does not implicate the political question doctrine, which concerns only the federal judiciary.

32. 3 U.S.C. $\$ \S 5,6,15(2000)$. Moreover, the legislative history of the Act unqualifiedly affirms an intent to commit the power to resolve electoral disputes to Congress rather than the Court:

The two Houses are, by the Constitution, authorized to make the count of electoral votes. They can only count legal votes, and in doing so must determine,

from the best evidence to be had, what are legal votes.... The power to determinc rests with the two Houses, and there is no other constitutional tribunal. H.R. No. 1638, 49th Cong., 1st Sess., 2 (1886) (Rep. Caldwell) (quoted in Bush v. Gore, 531 U.S. at 154 (Breyer, J., dissenting)). The sponsoring congressman explained:

The interests of all the States in their relations to each other in the Federal Union demand that the ultimate tribunal to decide upon the election of the President should be a constituent body, in which the States in their federal relationships and the people in their sovereign capacity should be represented.

18 Cong. Rec. 30 (1886) (quoted in Bush v. Gore, 531 U.S. at 154 (Breyer, J., dissenting)) And Senator Sherman, the sponsor in the Senate, cautioned against the Supreme Court's involvement: "It would be a very grave fault indeed and a very serious objection to refer a political question in which the people of the country were aroused, about which their feelings were excited, to this great tribunal.... It would tend to bring that court into public odium of one or the other of the two great parties." 17 Cong. Rec. 817-18 (1886) (Sen. Sherman). See generally Rachel E. Barkow, More Supreme than Court: The Fall of the Political Question Doctrine and the Rise of Judicial Supremacy, 102 Colum. L. Rev. 237 (2002) (stating that both the original understanding and subsequent history confirm that authority to resolve elector disputes was vested in the state legislatures, with review by Congress, and no role for the Supreme Court).

For the view that "it is at the least not obvious that the Constitution contains a demonstrable textual commitment of the Article II question to Congress," see Mark Tushnet, Law and Prudence in the Law of Justiciability: The Transformation and Disappearance of the Political Question Doctrine, 80 N. C. L. Rev. (2001). 
While the Electoral Count Act is not free of certain ambiguities and possible constitutional problems, it is relevant to consider what would have likely happened if the Court had abstained. Presumably, the recount would have continued. Under the simplest scenario, if the Florida process would have shown Governor Bush to be the winner, the election saga would have ended. ${ }^{33}$ Had the recount shown Vice President Gore to be the winner, the story becomes more complicated. First, based on one of the federal statutory provisions, ${ }^{34}$ the Republicancontrolled Florida legislature was poised to follow through with its plan to send a slate of Bush electors to Washington which would have competed with the Gore electors designated by the successful recount. ${ }^{35}$ Faced with opposing sets of electors when it met on January 6, 2001, the two newly-elected Houses of Congress, as specified by the Electoral Count Act, would "concurrently decide [which votes] were cast by lawful electors appointed in accordance with the laws of [Florida]." 36 Assuming congressional voting along party lines, the Republicancontrolled House of Representatives would have selected Governor Bush. Given the 50-50 Democrat-Republican composition of the Senate, a tie would have resulted, in which case the VicePresident-still Gore-would have cast the decisive ballot. Thus, the House and Senate would likely have split. The federal

33. Most reports from independent recounts have shown that Governor Bush would in fact have won. See, e.g., Audrey Hudson, Bush Is Victor Again in Latest Florida Tally, Washington Times A9 (Mar. 23, 2001) (reporting that an accounting firm audit of undervotes in six counties commissioned by Judicial Watch revealed that Bush would still have won; in fact, Bush gained 107-116 votes); Gore Missed Few Votes, Recount Review Finds, Wall St. J. A4 (Feb. 27, 2001) (reporting that Miami Herald's review found that Gore would have netted gain of no more than 49 votes had Miami-Dade County completed manual recount of 10,644 undervotes). Compare Extra! Gore Wins Florida! Hello?, The Nation 8 (April 2, 2001) (reporting that Palm Beach Post's recount of undervotes gave Gore 784 additional votes in Palm Beach County, and the butterfly ballots cost Gore an estimated 6,600 votes there).

34. 3 U.S.C. $\$ 2(2000)$ : "Whenever any State has held an election for the purpose of choosing electors, and has failed to make a choice on the day prescribed by law, the electors may be appointed on a subsequent day in such a manner as the legislature of such State may direct."

35. See Linda Kleindienst, Legislators Dodge Dispute On Vote Senate Delayed Elector Decision, South Florida Sun-Sentinel 19A (Dec. 17, 2000) (discussing the Florida legislature, which had called a special session to elect its own set of presidential electors, and its plans to appoint Bush electors despite the state supreme court's contrary decisions). For discussion of how such electors might be subject to constitutional challenge, see Jack M. Balkin, Bush v. Gore and the Boundary Between Law and Politics, 110 Yale L.J. 1407, 1423 n.60 (2001). Alternatively, even if the legislature had failed to act, those designated by the Florida Elections Canvassing Commission's earlier Nov. 26 certification, duly signed by Florida's governor, might have claimed to be the legitimate electors, thus similarly presenting Congress with competing slates.

36. 3 U.S.C. $\$ 15(2000)$ 
statute speaks to this outcome as well: "[I]f the two Houses shall disagree in respect of the counting of such votes, then, and in that case, the votes of the electors whose appointment shall have been certified by the executive of the State, under the seal thereof, shall be counted." ${ }^{37}$ Hence, the decision seemingly would have rested in the hands of the governor of Florida, Republican Jeb Bush, George W. Bush's brother ${ }^{38}$ who would have undoubtedly selected the Republican nominee, thus ending the presidential election.

Several ancillary points are worth noting in this connection. First, the second scenario's assumption that members of Congress would vote along party lines is not a foregone conclusion. If the completed recount were generally viewed to be fair, some House Republicans might have voted for Vice President Gore to preserve the intent of the voters of Florida. (However, given that seven members of the Supreme Court found fatal equal protection flaws with the method of the recount, Republicans would have had little trouble faulting it.) Second, during the Senate vote, debate might have surrounded Vice President Gore's casting the deciding ballot in his own favor as a conflict of interest. But given that the decision would then have proceeded to Florida's governor, Jeb Bush, the real conflict of interest controversy would have likely erupted then (if at all). Still, that family conflict, while perhaps adding to the drama, should not be determinative. The relevant fact is Jeb Bush's status as a Republican. The federal statute clearly granted decisionmaking authority to the state executive - a politically partisan individual - who would virtually always have some party affiliation. Since Florida's governor is a Republican, it should be obvious that he would select the Republican presidential candidate, absent some compelling contrary circumstances. Alternatively, Jeb Bush could have avoided any familial conflict and recused himself in favor of the Lieutenant Governor, Frank Brogan, who is also a Republican.

37. Id.

38. Based on 3 U.S.C. $§ 15$ 's "shall have been certified" language, some ambiguity exists as to whether it provides for prospective or only retrospective deference to the state governor's decision. If it were interpreted to permit Congress to only look retrospectively at which slate of electors that the state executive had certified, Jeb Bush, not the Florida legislature, would have had to certify the Bush electors for Bush to win. The Florida Supreme Court, however, might have ordered the Florida Governor to certify the Gore electors after the recount, presumably superceding the Secretary of State's Nov. 26 certification. Nevertheless, it is unlikely Jeb Bush would have complied, especially had Republicans favored the retrospective interpretation. 
In all, there is good reason to believe that the designated statutory framework would have fulfilled its drafters' intention of avoiding the pitfalls of the Hayes-Tilden aftermath. ${ }^{39}$ While a number of people, who foresaw some form of "constitutional crisis"40 that demanded the intervention of the Supreme Court, were distressed by the prospect of partisan controversy if the election of the President were to be determined by the political agencies provided in the Electoral Count Act, as pointed out by Professor Samuel Issacharoff, "it was, after all, a partisan election that was at stake. It hardly seems an affront to democratic self-governance to channel the ultimate resolution of a true electoral deadlock into other democratically-elected branches of government." ${ }^{41}$

\section{III}

In joining the election fray, the Supreme Court's ruling produced the most disappointing-and potentially destructiveoutcome: a 5-4 division, creating the reasonable perception of partisanship $^{42}$ (regardless of its existence in fact), halting the recount and making George W. Bush the President. The basis on which most of the general public understood the decision - that the five members of the Court who quite regularly make up its conservative majority (Chief Justice Rehnquist, and Justices Scalia, O'Connor, Kennedy and Thomas) voted to end the recount, while the four usual members of its liberal wing (Justices Stevens, Souter, Ginsburg and Breyer) wished to continue the

39. See supra note 32 . Indeed, even if the congressional process had failed to resolve the matter by inauguration day, the Presidential Succession Act, 3 U.S.C. $\S 17$, sets forth a remedy.

40. See infra text accompanying notes 69-80.

41. Samuel Issacharoff, Political Judgments, in Sunstein and Epstein, eds, The Vote: Bush, Gore and the Supreme Court at 73 (cited in note 19). Professor Issacharoff echoed the sentiment expressed by Justice Breyer, joined by Justices Stevens and Ginsburg: "However awkward or difficult it may be for Congress to resolve difficult electoral disputes, Congress, being a political body, expresses the people's will far more accurately than does an unelected Court. And the people's will is what elections are about." Bush v. Gore, 531 U.S. at 155 (Breyer, J., dissenting).

42. For example, Evan Schultz of Legal Times, while deliberately avoiding the question of whether the justices were actually partisan, nevertheless concluded that the "Supreme Court, always accused of being political, now has to face the fact that it looks downright partisan." Evan P. Schultz, Justice Unrobed, Legal Times 70 (Dec. 18, 2000) (emphasis added). Even supporters of Governor Bush, who maintained that the Court did not act out merely out of politics, said "the perception of rank politics was inaccurate but at the same understandable." Linda Greenhouse, Divining the Consequences of a Court Divided, N.Y. Times $\S 4$ (Dec. 17, 2000) (citing Professor Richard J. Pierce) (emphasis added). 
process in some form ${ }^{43}$-makes it easy to understand why allega-
tions of political bias erupted.4 These were especially fueled by
the President's power to designate new Justices and the persis-
tent reports that several conservative incumbents desired to re-
tire. ${ }^{45}$ Indeed, the notion that the Justices might become instru-

43. Bush v. Gore, 531 U.S. at $111-12,135-36,144-45,158$.

44. The quick and hostile reaction, outside legal academia and court watchers, is evidenced through various individual letters published by The Washington Post just days after the decision: "[T]he Rehnquist Court shattered the status quo of our belief in a Supreme Court that can rise above politics. It has dragged itself and the nation through a demoralizing display of partisanship." (Keith Ellis, Arlington); "A query for our esteemed Supreme Court justices: If the political victor in the historic recount case had been unknown to them, would their votes have been the same?" (Diane Heiman, Bethesda); "So much for the rule of law. The intellectual dishonesty of the Supreme Court decision fails to mask a raw partisan abuse of the unique powers granted by the Constitution. All that remains is to change the name of the institution from 'Supreme Court' to 'Final Political Instrument."' (Charles Blankstein, Falls Church). A Tuesday to Remember, Wash. Post A34 (Dec. 14, 2000).

For early critical response from academia, see Ledyard King, Regular People, Weighty Decision Put High Court in New Light, Gannett News Service (Dec. 14, 2000) (quoting Professor Michael Gerhardt stating "the court has transformed itself into a political institution"); Jeffrey Rosen, Disgrace, New Republic 18 (Dec. 25, 2000) (the Court has "made it impossible for citizens of the United States to sustain any kind of faith in the rule of law as something larger than the self-interested political preferences of [the conservative majority]"). Professor Akhil Amar was quoted as saying that "[m]any of us thought that courts do not act in an openly political fashion. So this decision comes as a startling event that has shaken constitutional faith," David G. Savage and Henry Weinstein, Supreme Court Ruling: Right or Wrong, L.A. Times A24, A25 (Dec. 21, 2000), and that "[w]hat will I tell my students? ... It will be my painful duty to say, 'Put not your trust in Judges." Joan Biskupic, Election Still Splits Court, USA Today 1A (Jan. 22, 2001). See also Andrew Greeley, Supreme Court Ditches Judicial Restraint, Chicago SunTimes 47 (Dec. 17, 2000) ("[J]udicial restraint goes out the window when the issue is awarding, by one vote, the presidency to the Bush dynasty.... The Supreme Court has decided George W. Bush is the president, and that's because the Supreme Court can say and do whatever it wants .... It was stolen from [Gore] ... by one vote on the Supreme Court"). For a further collection of similarly sharp criticisms, see Posner, Breaking the Deadlock at 200-01 n.70 (cited in note 21).

For subsequent extremely hostile commentary from both the academy and the bar, see Alan M. Dershowitz, Supreme Injustice: How the High Court Hijacked Election 2000 at 174 (Oxford U. Press, 2001) (asserting that the decision "may be ranked as the single most corrupt decision in Supreme Court history"); Vincent Bugliosi, The Betrayal of America: How the Supreme Court Undermined the Constitution and Chose Our President (Thunder's Mountain Press/Nation Books, 2001) (calling the majority Justices "criminals in the very truest sense of the word").

45. See Charles Lane, Is White House a Party to Retirement Plans?, Wash. Post A17 (May 7, 2001) ("O'Connor, 71, and Rehnquist, 76, are the two Justices on whom most of today's retirement speculation centers."); Jess Bravin, Richard B. Schmitt, and Robert S. Greenberger, Supreme Interests: For Some Justices, the Bush-Gore Case Has a Personal Angle, Wall St. J. A1 (Dec. 12, 2000) ("Chief Justice William Rehnquist ... and Justice Sandra Day O'Connor... have at times privately talked about retiring and would prefer that a Republican appoint their successors."); David Jackson, $A$ New Order in The Court? Next president may have to replace several justices - and alter its makeup, Seattle Times A3 (June 20,2000) (speculating on the retirement of Chief Justice Rehnquist, and Justices O'Connor and Stevens based on age and health factors). 
mental in selecting their own successors may have been felt to be particularly threatening to the defense of the awesome authority of judicial review that sees the appointment of members of the Court as probably the primary, and certainly the most honored, exercise of democratic control over a powerful unelected judiciary.

Seemingly, the Court itself recognized the potentially dangerous appearance of partisanship from its participation in the election controversy, as evidenced by its production of a terse, opaque, and manifestly brokered per curiam opinion in Bush v. Palm Beach County Canvassing Board ${ }^{46}$ the precursor to Bush v. Gore. Thus, on the day the final decision was rendered, Robert J. Samuelson commented in the Washington Post that the "narrowness of the decisions by the ... U.S. Supreme Court[] leave[s] the impression that, despite the high-minded legal justifications, the rulings simply veil individual or party choice." ${ }^{47}$

In the context of this controversy, it is critical to distinguish between judicial (or jurisprudential) ideology and political ideology (or crude partisanship). In view of the Justices' different backgrounds and fundamental values, the Supreme Court has nearly always been divided by ideological preference and philosophical approach. (And for the last three decades, the split has often ended up with five "conservatives" and four "liberals.") This is neither unseemly nor improper ${ }^{48}$ Genuine, intellectually defensible differences exist regarding the role of the Supreme Court in constitutional interpretation. For example, the debate on the appropriate balance between states' rights and federal power, at the forefront of the Rehnquist Court, has its origins with the Framers of the Constitution, signally illustrated by the split between Thomas Jefferson and Alexander Hamilton on the issue of whether Congress had power to charter a national bank. The tension between individual rights versus government power, and between the strict separation of congressional and presidential powers versus functional solutions to the

46. 531 U.S. $70(2000)$.

47. Robert J. Samuelson, Self-Inflicted Wound, Wash. Post A47 (Dec. 12, 2000).

48. See Greenhouse, N.Y. Times at $\$ 4$ (cited in note 42) ("That justices embrace particular ideologies is neither surprising nor in any way illegitimate; it is part of how they came to be selected. In a culture where political differences are so often packaged as lawsuits, political sophistication is an asset to any judge."); Ronald Dworkin, $A$ Badly Flawed Election, N.Y. Review 53 (Jan. 11, 2001) ("The 5-4 decision would hardly have been surprising, or even disturbing, if the constitutional issues were ones about which conservatives and liberals disagree as a matter of constitutional principle."). 
workings of our national government, are additional longstanding jurisprudential differences within the Court (and the nation).

To make the "ideology vs. partisanship" inquiry, one must-regardless of one's view of their merits-examine the individual Justices' proffered positions for consistency with their respective judicial philosophies as reflected in their prior jurisprudence. Unfortunately, doing so for all nine members of the Court does not make it easy to dispel the appearance of partisanship in the Bush v. Gore decision.

First, the Article II argument, supported by the concurrence of Chief Justice Rehnquist, joined by Justices Scalia and Thomas - that the Florida Supreme Court's interpretation of state election law was so unreasonable as to conflict with Article II's command that state legislatures direct the appointment of electors $^{49}$ - may be sought to be explained on a nonpartisan basis: Rather than constituting an act of politically biased activism, it was a cure for such unprincipled, partisan (pro-Gore) activism (usurpation of the state legislature's will) by the Florida Supreme Court. ${ }^{50}$ Still, the Rehnquist-Scalia-Thomas ruling appears to be strikingly at odds with their broader views on federalism. Such oversight of a state court's interpretation of state statutes does not correspond to their usual strong respect for state autonomy. ${ }^{51}$ Moreover, the situation was not one where the Florida court's alleged impropriety would stand had the Supreme Court declined to intervene. Rather, as described above, if the Court had stayed out, the matter would have been resolved by Congress. In addition, none of the four liberals, ordinarily much more sympathetic to exertions of national power that impinge on state sovereignty, joined the position of the Rehnquist concurrence.

49. Bush v. Gore, 531 U.S. at 112-22.

50. Another nonpartisan ground for the Court's ruling - that it spared the nation from experiencing a "constitutional crisis"-is discussed infra in text accompanying notes 69-80.

51. See, e.g., United States v. Lopez, 514 U.S. 549 (1995); Seminole Tribe of Florida v. Florida, 517 U.S. 44 (1996); City of Boerne v. Flores, 521 U.S. 507 (1997); College Savings Bank v. Florida Prepaid Postsecondary Educ. Expense Fund, 527 U.S. 666 (1999); Florida Prepaid Postsecondary Educ. Expense Bd. v. College Savings Bank, 527 U.S. 627 (1999); United States v. Morrison, 529 U.S. 598 (2000); Kimel v. Florida Bd. of Regents, 528 U.S. 62 (2000); Bd. of Trustees of U. of Alabama v. Garrett, 531 U.S. 356 (2001). Furthermore, in U.S. Term Limits, Inc. v. Thornton, 514 U.S. 779, 845 (1995), specifically in the federal election context, Justice Thomas, joined by Chief Justice Rehnquist, Justice Scalia, and Justice O'Connor, dissented to argue that the Court should not interfere with a state's eligibility requirements for congressional elections. These justices declined such passivity here. 
Second, as noted above, seven Justices found an equal protection violation based on the manner of the recount. ${ }^{52}$ This majority included all of the Court's five usual conservatives, an unlikely group to broaden the reach of equal protection doctrine..$^{53}$ As Linda Greenhouse observed in the New York Times, "the majority's ideology, which includes deference to the states and a high threshold for getting into federal court with untested

52. Bush v. Gore, 531 U.S. at 110-11.

53. Because of his length of service on the Court, Chief Justice Rehnquist's reluctance is most clear. See, e.g., Richardson v. Ramirez, 418 U.S. 24, 56 (1974) (Rehnquist, J.) (holding that disenfranchisement of convicted felons did not deny equal protection); Mahan v. Howell, 410 U.S. 315, 333 (1973) (Rehnquist, J.) (upholding state legislative reapportionment over dilution challenge brought under the Equal Protection Clause); Salyer Land Co. v. Tulare Lake Basin Water Storage Dist., 410 U.S. 719, 734-35 (1973) (Rehnquist, J.) (upholding law permitting only landowners to vote in "water storage districts" elections and apportioning votes according to the assessed valuation of the land within the districts); Ball v. James, 451 U.S. 355, 371-72 (1981) (upholding limitation of voting in water district to landowners on a "one acre, one vote" basis); Holt Civic Club v. Tuscaloosa, 439 U.S. 60, 74-75 (1978) (Rehnquist, J.) (upholding extension of city's police and sanitary regulations and its business-licensing powers to residents of adjacent unincorporated communities, but not permitting them to vote in city elections); Rosario $v$. Rockefeller, 410 U.S. 752, 760-62 (1973) (upholding requirement that voters enroll in the party of their choice at least 30 days before the November general election in order to vote in the next party primary); Kusper v. Pontikes, 414 U.S. 51, 65 (1973) (invalidating a law prohibiting a person "from voting in the primary election of one political party if he has voted in the primary of another political party during the preceding 23 months") (Rehnquist, J., dissenting); O'Brien v. Skinner, 414 U.S. 524, 531 (1974) (invalidating denial of absentee ballots to persons being held for trial and to convicted misdemeanants) (Rehnquist, J., dissenting).

In Davis v. Bandemer, 478 U.S. 109 (1986), holding a political gerrymandering claim to be justiciable under equal protection doctrine, Justice O'Connor, joined by Chief Justice Rehnquist, separately concurred to caution that the issue presented "a political question in the truest sense of the term," and to warn of the unacceptable risks that "judicial intervention on behalf of mainstream political parties... poses to our political institutions." Id. at 145,161 . While there have been very few cases in the last twenty years raising constitutional claims of abridgement of voting rights (in a nonracial context), there is no reason to believe that the views of Justices Scalia, Kennedy and Thomas would differ markedly from those of their more senior conservative colleagues.

As an indication of the seven-Justice majority's tentativeness to adopt equal protection reasoning - a readily understandable hesitation in light of its potential application to widespread differences throughout the country in voting systems (such as voting machines-either with levers or touch screens-versus paper ballots versus punch cards) and procedures for counting and recounting - the majority qualifies its holding: "Our consideration is limited to the present circumstances, for the problem of equal protection in election processes generally presents many complexities." Bush v. Gore, 531 U.S. at 109. "If variances among counties in a state in holding an election and counting ballots denies equal protection, then the entire election in Florida was unconstitutional and likely the elections in every state." Chemerinsky, 76 Notre Dame L. Rev. at 1107 (cited in note 10). "[T]he puzzle that the Supreme Court's decision creates is why the Equal Protection Clause does not require that states create uniform technologies for counting votes rather than just uniform standards for manual recounts." Balkin, 110 Yale L.J. at 1428 (cited in note 35). For a defense of the equal protection ruling and the argument that its scope is properly limited to recounts, see Nelson Lund, The Unbearable Rightness of Bush v. Gore, 23 Cardozo L. Rev. (forthcoming 2002). 
constitutional theories, would have predicted an opposite result." ${ }^{54}$ While the adoption of the equal protection argument by Justice Breyer and Justice Souter is less striking, the hypothesis that they joined the majority only out of hopes for a compromise to save the recount ${ }^{55}$ obviously does not help rebut characterization of the Bush v. Gore decision as a partisan ruling.

Finally, as also mentioned above, the basic 5-4 conservativeliberal split decided the issue of remedy-or lack thereof-to halt the recount, which effectively ended the election. ${ }^{56}$ Somewhat analogous to the Article II issue, ${ }^{57}$ the remedy inquiry required parsing the intent of the Florida legislature: whether it meant to take advantage of the federal statute's safe-harbor deadline $^{58}$ even though this "meant that thousands of contested machine-rejected ballots - many clearly indicating voter intent would remain uninspected by human eyes." 59 One might expect the pro-states' rights Justices to defer to the Florida Supreme Court's interpretation of the Florida legislature's intentions, and remand the case accordingly. However, in just one paragraph of its per curiam opinion, the five conservative Justices concluded that the Florida legislature wished to exercise the safe harbor ${ }^{60}$ and, thus, the Court halted any recounts. ${ }^{61}$ In sum, whether just

54. Greenhouse, N.Y. Times at $\$ 4$ (cited in note 42 ).

55. See Linda Greenhouse, Bush v. Gore: $A$ Special Report - Election Case a Test and Trauma for Justices, N.Y. Times A1 (Feb. 20, 2001) (describing Justices Breyer and Souter as using the equal protection ground to try to forge a compromise that would have allowed the count to resume).

56. Bush v. Gore, 531 U.S. at 110-11.

57. See supra text accompanying note 49-50.

58. 3 U.S.C. $\& 5$, established by Congress in 1887, provides that a state's determination of its electors, made pursuant to its election laws "at least six days prior to said time of meeting of the electors ... shall be conclusive, and shall govern in the counting of electoral votes." Section 5 "represented an effort by Congress to wash its hands of these [counting] matters after the disputed Hayes-Tilden election in 1876." Gary C. Leedes, The Presidential Election Case: Remembering Safe Harbor Day, 35 U. Richmond L. Rev. 237, 261 (2001) (quoting Michael J. Glennon, When No Majority Rules 31 (Congressional Quarterly Press, 1992)). Therefore, if met, the safe-harbor's irrebuttable presumption precludes any role for Congress in resolving electoral disputes, rendering moot the hypothetical scenarios set in motion by 3 U.S.C. $\$ 15$. See supra text accompanying notes 35 38.

59. Frank I. Goodman, Preface to The Supreme Court's Federalism: Real or Imagined? 574 The Annals 9, 15 (March 2001).

60. For the view that "here the U.S. Supreme Court appeared to be secondguessing the Florida court on a question of state law, a federal intrusion upon state autonomy more drastic than any of the congressional intrusions nullified by the Court in the decisions discussed [in note 51 supra]," see Goodman, Preface to The Supreme Court's Federalism at 14-15 (cited in note 59).

61. Bush v. Gore, 531 U.S. at 110-11. The majority's reliance on the lack of time for a recount remedy has struck some commentators as particularly perverse because the Court itself stayed the recount pending its decision. But it must be noted that Bush v. 
based on the 5-4 vote to stop the recount or a closer look at the ideological consistency of the underlying rationales, it is not easy to fault the conclusion that the decision "appear[s] driven not by the high politics of judicial philosophy but by naked partisanship."

It has been urged that the action of the Rehnquist Court's conservative majority in Bush v. Gore is not so surprising when viewed in the context of the Supreme Court's overall recent performance. ${ }^{63}$ Professor John Yoo submits that the Rehnquist Court specifically has not at all shied away from actively exercising its power of judicial review, including significant interventions in the area of voting rights and state election procedures. ${ }^{64}$ Through these efforts, Professor Yoo concludes, the Court has enlarged earlier forms of judicial review to one of judicial supremacy - not acting as an interpreter "but the interpreter of the

Gore ruled that the recount that had been going on violated equal protection.

62. Greenhouse, N.Y. Times at $\S 4$ (cited in note 42). See also Law Professors for the Rule of Law, 554 Law Professors Say... (advertisement), N.Y. Times A7 (Jan. 13, 2001) ("By stopping the vote count in Florida, the U.S. Supreme Court used its power to act as political partisans, not judges of a court of law."). The number of subscribers eventually reached 673 , from 137 law schools.

63. See Greenhouse, N.Y. Times at $\$ 4$ (cited in note 42); see also Larry D. Kramer, No Surprise. It's an Activist Court, N.Y. Times A33 (Dec. 12, 2000) (commenting that since the Rehnquist Court is best characterized by judicial supremacy and the extension of the doctrine of judicial review, their decision to intervene in the election is not surprising).

64. John C. Yoo, In Defense of the Court's Legitimacy, in Sunstein and Epstein, eds, The Vote: Bush, Gore and the Supreme Court at 234-35 (cited in note 19) (citing Shaw v. Reno, 509 U.S. 630 (1993); U.S. Term Limits v. Thornton, 514 U.S. 779 (1995)). Professor Yoo accurately adds that the Rehnquist Court

has reaffirmed the right to abortion and has placed limits on religion in the public sphere. In the federalism area, it has invalidated a series of federal laws in order both to protect state sovereignty and to limit the powers of the national government. One of the laws, the Violence Against Women Act, passed Congress by large majorities in both houses of Congress. In the race area, the Court has invalidated affirmative action in federal contracting and struck down redistricting that sought to maximize minority representation. On the First Amendment, the Court has invalidated federal laws so as to expand commercial speech and to protect indecent or pornographic material. It also has risked confrontation with the political branches by striking down federal laws solely on the ground that they violate the separation of powers. Hence, the Court has invalidated the Line Item Veto Act and reversed an effort to expand religious freedoms that the Court had cut back. (Indeed, the Religious Freedom Restoration Act of 1995 unanimously passed the House of Representatives and drew only three negative votes in the Senate.] This Court has been anything but shy in flexing its powers of judicial review to intervene in some of the most contentious issues of the day.

Yoo, In Defense of the Court's Legitimacy, in Sunstein and Epstein, eds, The Vote: Bush, Gore and the Supreme Court at 236-37 (cited in note 19). 
Constitution," 65 thus placing Bush v. Gore in the mainstream of the Rehnquist Court's flow.

Still, accepting this activist description of the Rehnquist Court does not significantly mitigate the widespread perceptions of partisanship generated by Bush v. Gore. Although the decision to review the case may have been consistent with the Court's arrogation of authority, the Justices' respective positions in the decision, as discussed above ${ }^{66}$ still appear to be difficult to reconcile with their normal approaches. Moreover, the distinction between the Court reviewing the rules and procedures under which elections are held and the Justices determining which of the two major party candidates shall be President of the United States may fairly be perceived as illustrating a difference between articulating principles of judicial philosophy and engaging in partisan politics. As Robert J. Samuelson commented, the decision has fostered the "belief that no one in a position of power (including a judge or Supreme Court Justice) can rise above partisan and personal preferences to defend some larger concept of national interest." ${ }^{.6}$

\section{IV}

Although debate over faithfulness of the Bush v. Gore decision to judicial ideals will resonate within legal academia for many years to come, there is reason to believe that the Court's credibility and the public's respect for it may not suffer more than temporarily. ${ }^{68}$ Two factors may distinguish Bush v. Gore

65. Yoo, In Defense of the Court's Legitimacy, in Sunstein and Epstein, eds, The Vote: Bush, Gore and the Supreme Court at 237 (cited in note 19). But see Nixon v. United States, 506 U.S. 224, 238 (1993) (dismissing claim involving the Senate's impeachment process as a political question).

66. See supra text accompanying notes $42-61$.

67. Samuelson, Self-Inflicted Wound at A47 (cited in note 47).

68. See generally Michael Klarman, Bush v. Gore: Through the Lens of Constitutional History, $89 \mathrm{Cal}$. L. Rev. 1721 (2001) (theorizing that Court's legitimacy largely rests on public opinion rather than the legal reasoning of its opinions and applying multifactor analysis - such as quantity, intensity, source, and duration of public disapproval-to predict that Bush v. Gore will likely not levy long-standing harm to the Court's standing).

That public opinion polls have shown no significant reduction in the Court's approval rating should not, however, be taken as demonstrating that the Court has lost no ground. Although in mid-January of this year, 59 percent of Americans approved of how the Court was doing its job, down only three points from August 2000, the political composition of the results changed dramatically. In August, 60 percent of Republicans and 70 percent of Democrats were supportive; in January, the figures were 80 percent of $\mathrm{Re}$ publicans and only 42 percent of Democrats. Wendy W. Simmons, Election Controversy Apparently Drove Partisan Wedge into Attitudes Towards Supreme Court, available at 
from other rulings that have wounded the Court's prestige and drained its institutional capital.

First, a substantial number of people believed that the nation was headed toward some form of "constitutional crisis" that the Supreme Court's intervention was necessary to avoid. ${ }^{69} \mathrm{Al}-$ though I have argued above that the dispute resolution process was working as expected, and that the political branches should have been able to adequately handle the various scenarios, ${ }^{70}$ many opinion leaders did not share this view. ${ }^{71}$ The media, whose interests are often served by hyperbole, joined in propagating this perception. For example, the cover of Newsweek pictured the Constitution with the word "CHAOS" emblazoned across it, ${ }^{72}$ and U.S. News titled its feature election story "Confusion Reigns." 73

Following the Supreme Court's decision, various commentators characterized the Justices as rescuing the nation from a dangerous impasse to be created by protracted and chaotic congressional bickering that might threaten the country's political stability. ${ }^{74}$ Not surprisingly, conservatives embraced this view.

<http:/www.gallup.com./poll/releases/pr010116.asp> (last visited Jan. 16 2001). Moreover, when asked whether Bush v. Gore "was based more on partisan politics, or more on an objective interpretation of the law," 65 percent of Gore voters but only 10 percent of Bush voters chose the former explanation. CBS News Poll, Dec. 14-16, 2000. Similarly, only 17 percent of Gore supporters thought the decision was "fair," as compared to 94 percent of Bush enthusiasts, CNN/USAToday/GallupPoll, Dec. 13, 2000, while the ruling caused 54 percent of Gore backers, as opposed to only 5 percent of those for Bush, to "lose confidence" in the Court. Id. Moreover, another post-discussion poll found that although "most Americans support the actions of the Supreme Court in the presidential dispute [and] believe the decision was fairly made," there were dramatic differences between black and white Americans and between white Republicans and white Democrats. James L. Gibson, Gregory A. Caldeira, and Lester K. Spence, The Supreme Court and the 2000 Presidential Election, unpublished manuscript, available at <http://www.artsci. wustl.edu/ legit/research.html> (last visited Sept. 7, 2001). Finally, this same survey showed that while only 29 percent of respondents thought that the justices based their votes in Bush v. Gore on their own preferences for president rather than the "legal merits of the case," nearly half of the Democrats felt otherwise. Id.

69. See, e.g., Robert Novak, From Legacy to Footnote, Chicago-Sun Times 43 (Dec. 14,2000 ) ("[T]he bare majority of the high court saved the country from this potential constitutional crisis resulting from Gore's doggedness").

70. See supra text accompanying notes 39-41.

71. See Linda Greenhouse, Bush v. Gore: A Special Report A1 (Feb. 19, 2001) (de. scribing the "belief among respected opinion leaders that a national crisis required the court's intervention").

72. Newsweek (cover) (Dec. 18, 2000).

73. U.S. News \& World Report X (Dec. 18, 2000)

74. See, e.g., Robert Justin Lipkin, A Derelict on the Waters of the Law?, Congress Monthly 3 (Jan/Feb. 2001) ("[T]he election 2000 controversy was stealing valuable time from the next administration and dangerously dividing the nation; the crisis needed resolution."); Leedes, 35 U. Richmond L. Rev. at 247 (cited in note 58) (praising the finality 
For example, Judge Richard Posner questioned, "What exactly is the Supreme Court good for if it refuses to examine a likely constitutional error that if uncorrected will engender a national crisis?"75 Walter Berns likewise credited the Court with "sav[ing] us from a devastating political outcome ... an absolute mess." More significantly for our purposes, some who supported Vice President Gore, or who otherwise strongly disagreed with the Court's outcome, nonetheless acknowledged this salutary effect of the decision. Thus, Professor Cass Sunstein, a moderate liberal, reflected that the Court "might actually have done something that is to the nation's benefit. From the point of view of statesmanship, the Court may end up looking well." his concession speech, Vice President Gore himself led the call to accept the finality and legitimacy of the Court's decision, reassuring the nation that no constitutional controversy remained now that the Court had spoken. ${ }^{78}$

Similarly, much of the American public, regardless of its politics, may have shared a collective sigh of relief that the election was finally over. The Chicago Tribune reported that "landslide majorities of Americans had told pollsters they wanted the justices to resolve the Florida case," ${ }^{, 79}$ presumably with the attitude that better that it be done, than that it be done right. A Wall Street Journal editorial captures this sentiment: "We expect

attained by the Court's decision given the approaching brink of a crisis that may have otherwise occurred with conflicting sets of electors).

75. Benjamin Wittes, Maybe the Court Got It Right: A Judge's Defense of the Florida Election Decision, Wash. Post (Feb. 21, 2001), available at <http://washingtonpost. $\mathrm{com} / \mathrm{wp}$-dyn/articles/A32533-2001Feb20.html) > (quoting Posner). See also Richard Posner, The Triumph of Experience, Harper's 32 (May 2001). For fuller development of Judge Posner's view that Congress would not have behaved in a statesmanlike fashion, but rather would produce a scene of partisanship run amok, see Posner, Breaking the Deadlock at $162-63$ (cited in note 21 ).

76. Jonathan Groner, Will Election Case Do Damage to the Judiciary?, Legal Times 15 (Dec. 18, 2000). The argument is further developed in Balkin, 110 Yale L.J. at 1436-37 (cited in note 35): "Republicans hungered to regain control of the presidency after eight years. ... [In Congress], they may well have overreacted and behaved very badly indeed. It was possible that whatever the Congress did would be seen widely as the rawest form of politics, with no concern for fairness or justice. This would have delegitimated the new president and prevented him from governing effectively."

77. Groner, Will Election Case Do Damage to the Judiciary? at 15 (cited in note 76).

78. Al Gore, Transcript of Concession Speech. And the public appears to have heeded Gore's call. Even though only a bare majority of Americans initially agreed with the Court's ruling, $80 \%$ of respondents to a CNN/USA Today/Gallup poll conducted on December 13, 2000 recognized Bush as the legitimate winner of the 2000 presidential election. David W. Moore, Eight in Ten Americans to Accept Bush as "Legitimate," Gallup News Service (Dec. 14, 2000), available at <http://www.gallup.com/poll/releases/ pr001214.asp> (visited April 7, 2001).

79. Don't Blame the Supreme Court, Chicago Trib. 28 (Dec. 15, 2000). 
most Americans will get over this election pretty quickly. They realize the machinery hit an alligator in the road and the U.S. Supreme Court had no choice but to tow us home." ${ }^{80}$ As a consequence, the Court's vulnerability to invective and other forms of attack in such highly disputed matters as segregation, school prayer, and abortion, where all those on the "losing" side deeply resented the Justices' "wrong" decision, is greatly mitigated when the "losers" see some virtue in the Court's action.

Second, unlike prior controversial cases that have had a profound impact on the Court's standing, the matter of Bush v. Gore is over and will not reopen in the Judicial Branch. ${ }^{81}$ This final quality of the decision may be contrasted with the ongoing nature of the Court's role in other areas where the Justices have faced widespread criticism and suffered various wounds. During the New Deal era, the Court confronted severe public hostility for its repeated invalidation of national economic recovery legislation aimed at ending the Great Depression. ${ }^{82}$ The racial segregation cases caused intense controversy over a much longer period, beginning with Brown v. Board of Education, ${ }^{83}$ and continuing regularly for at least two decades. ${ }^{84}$ The clash over school prayer, starting in the early $1960 \mathrm{~s},{ }^{85}$ has yet to fully abate. ${ }^{86}$ Finally, with abortion, the Court absorbed negative reaction in case after case following Roe $v$. Wade from those government officials and members of the public who disagreed with

80. The Agenda, Wall St. J. A16 (Dec. 15, 2000).

81. It remains to be seen whether Democrats in the Senate will invoke the ruling in Bush v. Gore in responding to President Bush's judicial nominations, especially to the Supreme Court. "They can repeatedly remind people that the Court decided the election and play up the Court's conflict of interest in choosing the president who would choose the Justices' colleagues and successors. ... They can also emphasize the injustice of letting the Court appoint the person who will nominate their colleagues and successors and send the Court careening even more strongly to the right." Balkin, 110 Yale L.J. at 1456, 1458 (cited in note 35). Still, such use of the decision appears quite different, in terms of public antipathy toward the Court, than a subsequent judicial ruling that directly produces more of the same kind of perceived injurious results as did the earlier judgment.

82. During a two year period, the Court struck down six major New Deal statutes.

83. 347 U.S. 483 (1954).

84. After Brown, cases involving the enforcement of school desegregation flooded the lower federal courts, and the Supreme Court was forced to render numerous critical decisions. See, e.g., Brown v. Bd. of Educ. (II), 349 U.S. 294 (1955); Cooper v. Aaron, 358 U.S. 1 (1958); Griffin v. Prince Edward County Sch. Bd., 377 U.S. 218 (1964); Green v. New Kent County Sch. Bd., 391 U.S. 430 (1968); Swann v. Charlotte-Mecklenburg Bd. of Educ., 402 U.S. 1 (1971); Keyes v. School Dist. No. 1, Denver, Colorado, 413 U.S. 189 (1973); Milliken v. Bradley, 418 U.S. 717 (1974). (1963)

85. See Engel v. Vitale, 370 U.S. 421 (1962); Sch. Dist. v. Schempp, 374 U.S. 203

86. Sce Santa Fe Ind. Sch. Dist. v. Doe, 530 U.S. 290 (2000). 
either its premises or result or both. ${ }^{87}$ In addition, all four areas just discussed produced numerous lower court cases, each providing renewed opportunity for public dissatisfaction with the Court and calls for political reprisals.

In contrast, Bush v. Gore is important, not because it resolved a substantive question involving Florida's selection of presidential electors, or generated some enduring doctrine or principle likely to spark an ongoing democratic debate. Rather, the case was momentous because it resulted in the election of President George W. Bush, a matter virtually impossible ever to arise again. The equal protection principle on which the Court based its decision will surely be invoked in the future by losing candidates of every kind. But, for a variety of reasonsespecially the fact that it calls into question issues that pervade election systems throughout the country ${ }^{88}$-it is highly doubtful that the Supreme Court will rely on it again for a finding of unconstitutionality. ${ }^{89}$ Furthermore, unlike law professors, political figures, and a few similarly minded persons, most Americans have a short memory for such events. Regardless of party, most of the country, following the urging of Vice President Gore, have accepted the fact that George W. Bush will occupy the White House until at least 2004. ${ }^{90}$ Stimulated by the fast-shifting nature of media coverage, the public's political attention quickly turned to other aspects of the Bush Administration and its activities. New scandals and crises rapidly stole the headlines, and, within days, even comedians abandoned election jokes in favor of the new president's timely gaffes. Without the recurrent irritant posed by ongoing litigation involving sensitive issues such as economic welfare, race, prayer, and abortion, there is a real chance that Bush v. Gore will not fall into the category of "self

87. 410 U.S. $113(1973)$

88. See B.J. Palermo, Rights Groups Latch Onto Bush v. Gore, Natl. L.J. A1 (May 21,2001 ) (reporting "lawsuits across the country" using rationale to challenge use of punch-card voting machines).

89. In fact, the Court went out of its way to limit the underlying equal protection rationale to the unique context of the case, seeking to avoid federal judicial supervision of all elections contests, by the unambiguous edict that "[o]ur consideration is limited to the present circumstances, for the problem of equal protection in election processes generally presents many complexities." See Bush v. Gore, 531 U.S. at 109 . Even if the equal protection rationale is utilized in future voting rights cases, it will almost surely never arise again to decide a presidential election.

90 . One public opinion poll, taken shortly after the election, found that 85 percent of respondents perceived the Bush Presidency as legitimate. Gibson, Caldeira and Spence, The Supreme Court and the 2000 Presidential Election (cited in note 68). 
inflicted wounds"91 that were fully realized, best characterized by Dred Scott. Only time will tell. ${ }^{92}$

91. Charles Evans Hughes, The Supreme Court of the United States: Its Foundations, Methods and Achievements 50 (Columbia U. Press, 1928).

92. Poll responses early in $2001 \mathrm{did}$ "not seem consistent with the view that the Court inflicted a serious wound on itself' because of Bush v. Gore. See James L. Gibson, Gregory A. Caldeira, and Lester K. Spence, The Legitimacy of the U.S. Supreme Court, unpublished manuscript, available at <http://www.artsci.wustl.edu/ -legit/research.html> (visited Sept. 7, 2001). 